\title{
CHARAKTERYSTYKA ZBIORU DRUKÓW Z XVI WIEKU BIBLIOTEKI WYŻSZEGO SEMINARIUM DUCHOWNEGO METROPOLII WARMIŃSKIEJ „HOSIANUM” W OLSZTYNIE
}

Zbiór starych druków z XVI wieku Biblioteki Wyższego Seminarium Duchownego Metropolii Warmińskiej „Hosianum” w Olsztynie obejmuje 1559 druków, z czego 24 stanowią druki współoprawne z inkunabułami. Część druków jest współoprawna z drukami późniejszymi (XVII-XVIII w.). Niektóre klocki składają się nawet z kilkudziesięciu druków współoprawnych, np. XVI Q 106 składa się z 63 druków, XVI Q 108 - z 37 druków, Sd 399 - z 36 druków. Rekordzista liczy 169 druków współoprawnych (XVI Q 107).

\section{Pochodzenie druków z XVI wieku}

Druki z XVI wieku w zbiorach Biblioteki „Hosianum” nie są kolekcją jednolitą, bowiem obecna biblioteka po II wojnie światowej zgromadziła zabytkowe księgi z terenu całej diecezji warmińskiej, zaś część ksiąg uległa zniszczeniu bądź zmieniła właścicieli.

Najwięcej starych druków z XVI wieku trafiło do Biblioteki „Hosianum” z Braniewa - 628 (w tym: 519 z Liceum Hosianum, 91 z kolegium jezuitów, 10 z Alumnatu Papieskiego, 5 z seminarium duchownego, 2 z parafii, 1 z Sodalicji Mariańskiej przy kolegium jezuitów). Kolegium jezuitów w Braniewie od począt$\mathrm{ku}$, czyli od $1565 \mathrm{roku}$, posiadało swoją bibliotekę. Jej fundament stanowił księgozbiór przejęty po franciszkanach, w którym znajdowały się również książki po kanoniku warmińskim Tomaszu Wernerze z 1498 roku¹. Liczył on 320 wolumi-

* Ks. Tomasz Garwoliński - mgr lic. teologii, kustosz dyplomowany, dyrektor Biblioteki Wyższego Seminarium Duchownego Metropolii Warmińskiej „Hosianum” i Wydziału Teologii Uniwersytetu Warmińsko-Mazurskiego w Olsztynie, e-mail: tomgar@uwm.edu.pl

${ }^{1}$ T. Borawska, Die Bibliothek der Franziskaner in Braunsberg. Versuch einer Rekonstruktion, „Zeitschrift für die Geschichte und Altertumskunde Ermlands” (dalej: Zeitschrift), 49 (1999) s. 1535; J. Obłąk, O początkach kolegium jezuickiego i Seminarium Duchownego w Braniewie, „Studia Warmińskie" (dalej: SW), 5 (1968) s. 5-41; L. Grzebień, Organizacja bibliotek jezuickich w Polsce 
nów. Biblioteka otrzymała dary książkowe od kard. Stanisława Hozjusza i kapituły we Fromborku. W późniejszym okresie była uzupełniana i rozszerzana przez jezuitów i fundatorów. Jednak większość książek w 1626 roku została wywieziona do Szwecji (ponad 2600 dzieł) i pozostaje do dziś w Bibliotece Uniwersyteckiej w Uppsali². Potem podjęto działania zmierzające do odbudowania księgozbioru. W 1820 roku książki włączono do zasobów biblioteki Liceum Hosianum, a później Akademii Państwowej w Braniewie ${ }^{3}$.

Następna pod względem liczby druków z XVI wieku jest Biblioteka Kapituły Kolegiackiej w Dobrym Mieście (353). Pierwsza wzmianka o istnieniu księgozbioru kapituły pochodzi z 1379 roku. Pod koniec XVI wieku liczył on około 200 pozycji, a w 1811 roku - 1 473. W czasie najazdu Szwedów miasto zostało splądrowane. Jednak biblioteka ocalała. Obok przeważających dzieł teologicznych i prawniczych, znajdowała się w niej spora liczba książek filozoficzno-historycznych i geograficznych, a literaturę piękną reprezentowały książki niemieckie, francuskie i polskie 4 .

Z biblioteki konwentu bernardynów w Barczewie pochodzi 161 druków z XVI wieku. Bernardynów do Barczewa sprowadził w 1598 roku bratanek króla Stefana Batorego - biskup warmiński kardynał Andrzej Batory. On też przeprowadził remont i wyposażył klasztor, w którym wcześniej przebywali bracia mniejsi franciszkanie ${ }^{5}$. Rozwój księgozbioru zapewne miał związek z tym, że w 1709 roku z powodu szalejącej zarazy przeniesiono do Barczewa studium teologii z Warszawy.

Sto starych druków z XVI wieku pochodzi z Fromborka (w tym: 47 z archiwum biskupiego, 31 z kolegium wikariuszy katedralnych, 11 z kurii biskupiej, 9 z Warmińskiej Kapituły Katedralnej, 2 z katedry). Początki biblioteki Kapituły Katedralnej sięgają XIII wieku. Opiekę nad nią sprawował każdorazowy kustosz. Znajdowały się w niej przede wszystkim księgi liturgiczne (mszały i brewiarze), teologiczne, prawnicze, a także medyczne i dzieła pisarzy starożytnych. Księgi

od XVI do XVIII wieku, „Archiwa, Biblioteki i Muzea Kościelne”, 30 (1975) s. 265; J.Z. Lichański, Biblioteka ,Collegium Societatis Jesu” w Braniewie. Próba charakterystyki, SW, 27 (1990) s. 309324.

2 J. Wojtkowski, Stare druki w Bibliotece Wyższego Seminarium Duchownego Metropolii Warmińskiej „,Hosianum”, „Fides. Biuletyn Bibliotek Kościelnych” (dalej: Fides), 1-2 (2009) s. 3233; J. Trypućko, Katalog księgozbioru Kolegium Jezuitów w Braniewie zachowanego w Bibliotece Uniwersyteckiej w Uppsali, t. 1-3, Warszawa-Uppsala 2007.

${ }^{3}$ A. Szorc, Kolegium jezuickie w Braniewie i jego księgozbiór 1565-1626, Olsztyn 1998, s. 24-25; F. Hipler, Analecta Warmiensia. Studien zur Geschichte der ermländischen Archive und Bibliotheken, Zeitschrift, 5 (1884) s. 316-488; A. Kopiczko, Duchowieństwo katolickie diecezji warmińskiej w latach 1525-1821, cz. 1, Olsztyn 2000, s. 121-122; Encyklopedia wiedzy o jezuitach na ziemiach Polski i Litwy 1564-1995, red. L. Grzebień, Kraków 1996, s. 64-65; Lichański, Biblioteka ,Collegium Societatis Jesu” w Braniewie, s. 310; T. Garwoliński, Dzieje Biblioteki „Hosianum” (Braniewo-Olsztyn: 1565-2008), Fides, 1-2 (2008) s. 15.

${ }^{4}$ Kopiczko, Duchowieństwo katolickie diecezji warmińskiej, s. 120-121; A. Birsch-Hirschfeld, Geschichte des Kollegiatsstifts in Guttstadt 1341-1811, ein Beitrag zur Geschichte des Ermland, Zeitschrift, 24 (1930/1932) s. 733-734.

${ }^{5}$ Poczet biskupów warmińskich, red. S. Achremczyk, Olsztyn 2008, s. 189-190. 
pozaliturgiczne kanonicy najczęściej gromadzili podczas studiów i podróży. Właśnie XVI wiek uważany jest za okres znakomitego rozwoju biblioteki kapitulnej we Fromborku. Inwentarz z 1598 roku wymienia w niej następujące działy: teologię, prawo, historię, filozofię, retorykę, gramatykę, medycynę, poezję, muzykalia. W czasie najazdu Szwedów w 1626 roku biblioteka Kapituły Katedralnej utraciła ok. 700 woluminów. W XVIII wieku liczyła 703 księgi. Biblioteka kapituły we Fromborku przetrwała do 1945 roku. Potem jej zbiory, które ocalały po wydarzeniach z początku 1945 roku, przewieziono do Biblioteki „Hosianum”.

Bibliotekę posiadało również kolegium wikariuszowskie przy katedrze fromborskiej. Została ona założona na początku XIII wieku?

Biskupi warmińscy rezydujący w Lidzbarku posiadali bogate zbiory, w których znajdowały się komentarze do sentencji Piotra Lombarda, dekretały, Biblia i pomoce duszpasterskie. Biblioteka lidzbarska musiała być bardzo znacząca, ponieważ korzystał z niej kardynał Stanisław Hozjusz, pisząc dzieła oparte zwłaszcza na Piśmie Świętym i dziełach ojców Kościoła. Wielkie zasługi w powiększaniu biblioteki miał bp Jan Dantyszek, który sprowadzał książki prawnicze, filozoficzne i teologiczne. O bibliotece na zamku w Lidzbarku mówiono, że należy do najznaczniejszych ${ }^{8}$. Niestety, w czasie wojny północnej w 1704 roku większość zbiorów wywieźli Szwedzi. Niektóre zaginęły po śmierci bpa Andrzeja Załuskiego (1711 r.). Księgozbiory kolejnych biskupów nie pozostawały już w Lidzbarku, lecz były zapisywane w testamentach innym instytucjom. Po przeniesieniu stolicy biskupiej do Fromborka (1841 r.), resztki biblioteki trafiły do biblioteki seminaryjnej w Braniewie i kapitulnej we Fromborku .

Dwadzieścia siedem druków z XVI wieku pochodzi z Reszla (w tym: 22 z kościoła archiprezbiterialnego, 3 z kolegium jezuitów, 2 z bractwa kapłańskiego). Pozostałe pochodzą z różnych bibliotek parafialnych, instytucji, stowarzyszeń i zgromadzeń oraz od księży i osób prywatnych. Są to przede wszystkim księgi liturgiczne (mszały, brewiarze, agendy, rytuały, psałterze), pomoce homiletyczne, komentarze do Pisma Świętego, dzieła z dziedziny medycyny, przyrodoznawstwa czy dzieła pisarzy starożytnych i epoki humanizmu ${ }^{10}$.

W rozpowszechnianiu książki na Warmii ogromną rolę odegrała drukarnia założona w 1589 roku w Braniewie. Do 1697 roku pozostawała ona w rękach prywatnych, a potem przeszła w ręce jezuitów. Drukowano w niej przede wszystkim książki religijne. Autorami zaś byli głównie jezuici i duchowni diecezji warmińskiej. Drukarnia wydawała agendy, śpiewniki, Pismo Święte, zarządzenia urzędowe i dekrety biskupów warmińskich. Jezuici drukowali dzieła teologiczne, polemiczne, ascetyczne, historyczne, dewocyjne i panegiryczne, a także podręcz-

${ }^{6}$ Kopiczko, Duchowieństwo katolickie diecezji warmińskiej, s. 119-120; T. Borawska, Życie umystowe na Warmii w czasach Mikołaja Kopernika, Torun 1996, s. 113-114.

${ }^{7}$ Kopiczko, Duchowieństwo katolickie diecezji warmińskiej, s. 121.

${ }^{8}$ W 1633 r. znajdowało się w niej 784 woluminów - E. Brachvogel, Die Bibliothek der Burg Heilsberg, Zeitschrift, 23 (1929) s. 276, 303-358; Wojtkowski, Stare druki w Bibliotece Wyższego Seminarium Duchownego, s. 33-34.

${ }^{9}$ Kopiczko, Duchowieństwo katolickie diecezji warmińskiej, s. 118-119.

${ }^{10}$ Tamże, s. 123. 
niki szkolne. W latach 1589-1773 w oficynie braniewskiej ukazało się łącznie ok. 600 druków $^{11}$.

\section{Miejsce wydania}

W XVI wieku w zachodniej Europie oficyny drukarskie były w ponad 250 miastach, szczególnie w większych centrach i ośrodkach uniwersyteckich ${ }^{12}$. Warmińskie stare druki z XVI wieku były drukowane praktycznie w całej Europie. Pochodzą z osiemdziesięciu dziewięciu ośrodków drukarskich od 497 wydawców. Prawie połowa (49,9\%) była drukowana w Niemczech, 14,65\% - we Francji i Alzacji, 12,47\% - w Szwajcarii, 8,65\% - w Niderlandach, 7,79\% - w polskich drukarniach, 4,49\% - w Italii.

W drukarniach niemieckich wydano 756 druków (w tym: Kolonia 282, Wittenberga 65, Ingolstadt 57, Lipsk 52, Helmstedt 40, Moguncja 38, Frankfurt nad Menem 37, Tybinga 31, Jena 20, Norymberga 19, Dillingen 14, Frankfurt nad Odrą 13, Augsburg 12, Neustadt an der Haardt 10, Erfurt 7, Eisleben 6, Heidelberg 6, Monachium 6, Freiberg 5, Magdeburg 5, Pforzheim 5, Drezno 3, Fryburg Bryzgowijski 3, Herborn 3, Hamburg 2, Hanau 2, Servesta 2, Siegen 2, Ulm 2, Greifswald 1, Konstancja 1, Münster 1, Padeborn 1, Ratyzbona 1, Würzburg 1, Zwickau 1). We Francji i Alzacji wydrukowano 222 księgi (w tym: Paryż 69, Lyon 67, Strasbourg 46, Haguenau 31, Douai 2, Fribourg 2, Nancy 2, Arras 1, Miluza 1, Rupella 1), w Szwajcarii - 189 (w tym: Bazylea 161, Genewa 14, Zurych 10, Lozanna 3, Berno 1), w Niderlandach - 131 (w tym: Antwerpia 111, Leuven 15, Ličge 3, Amsterdam 1, Zwolle 1), w Polsce i Litwie - 118 (w tym: Kraków 59, Wilno 26, Poznań 14, Gdańsk 9, Nysa 3, Zgorzelec 2, Braniewo 1, Oliwa 1, Toruń 1, Wrocław 1, Zamość 1), we Włoszech - 68 (w tym: Wenecja 38, Rzym 12, Mediolan 7, Bolonia 2, Ferrara 2, Neapol 2, Trino 2, Brescia 1, Bressanone 1, Pawia 1), w Prusach (Królewiec) - 10, w Austrii (Wiedeń) - 10, w Czechach - 3 (w tym: Bruck 1, Kralice 1, Ołomuniec 1), w Wielkiej Brytanii - 3 (Oxford 2, Stafford 1), w Danii (Kopenhaga) - 2 i po 1 starodruku w Węgrzech (Debreczyn), Portugalii (Lizbona) i Chorwacji (Varaždin).

Najwięcej warmińskich starych druków z XVI wieku wydano w: Kolonii (282), Bazylei (161), Antwerpii (111), Paryżu (69), Lyonie (67), Wittenberdze (65) i Krakowie (59).

Drukarstwem zajmowały się całe rodziny, w których zawód był przekazywany z pokolenia na pokolenie. Najsłynniejszym i znanym w całej Europie drukarzem był Christophe Plantin (1514/1520-1589). W Antwerpii początkowo zajął się handlem księgarskim i introligatorstwem. W 1555 roku wydał pierwszą książkę jako mistrz drukarski. W latach 1563-1567 powstała spółka drukarska z udziałem Plantina, co przyczyniło się do niebywałego rozwoju jego oficyny. Przywileje (np. na wydawanie mszałów) oraz protekcja wysoko postawionych osób duchownych i świeckich, a także przyjaźń z wieloma uczonymi i humanistami euro-

\footnotetext{
11 Tamże, s. 125.

${ }^{12}$ C. Clair, A History of European Printing, Londyn-Nowy Jork-San Francisco 1976, s. 120.
} 
pejskimi zapewniły rozwój drukarni przez długie lata ${ }^{13}$. W zbiorach Biblioteki „Hosianum” znajduje się 51 dzieł wydrukowanych w oficynie Plantina ${ }^{14}$, w tym Theatrum orbis terrarum Abrahama Orteliusa z 1592 roku.

Początki oficyny Quenteliana z Kolonii sięgają Heinricha Quentela ze Strasbourga (†1501 r.), największego kolońskiego drukarza okresu inkunabułów ${ }^{15}$. Z tej drukarni pochodzi aż 96 druków z XVI wieku, znajdujących się w bibliotece seminarium duchownego ${ }^{16}$.

Inną znaną oficyną była oficyna Birckmannów, znajdująca się w Kolonii, a działająca od 1526 roku $^{17}$. W zbiorach Biblioteki „Hosianum” znajdują się 53 dzieła wydane w tej drukarni ${ }^{18}$.

Również w Kolonii w latach 1557-1588 pracował drukarz Maternus Cholinus ${ }^{19}$. W zbiorach biblioteki seminaryjnej znajduje się 70 dzieł wydanych w jego oficynie, w tym agendy warmińskie oraz dzieła Hozjusza i Kromera ${ }^{20}$.

Oficyna Frobeniana działała w Bazylei od przełomu XV-XVI wieku. Drukowała ona prace Erazma z Rotterdamu, wydawnictwa w języku greckim i łaciń-

${ }^{13}$ B. Górska, Krzysztof Plantin i Officina Plantiniana, Wrocław 1989, s 19-20. 54; J. Gwioździk, E. Różycki, Druki XVI wieku w zbiorach Biblioteki Katedralnej we Lwowie, Warszawa 2008, s. 5253.

${ }^{14}$ Sd 39,1-2 adl.; Sd 43,1-4 adl.; Sd 387,1-3 adl.; Sd 461; Sd 516; Sd 812,1-6 adl.; Sd 929; Sd 974,1-5 adl.; Sd 1049,1-2 adl.; Sd 1242,1-2 adl.; Sd 1350; Sd 1351; Sd 1351bis; II-3086; II-3105; II3106/1-2; II-3135/1; De 253; De 276,1-2 adl.; Fb 688; Lg 597; XVI F 30; XVI F 117,1-2 adl.; XVI O 60,1-2 adl.; XVI O 73; XVI O 81; XVI O 85,1 adl.; XVI O 151; XVI Q 51; XVI Q 147,3 adl.

${ }^{15}$ Gwioździk, Różycki, Druki XVI wieku, s. 57.

${ }^{16}$ Inc. 30,1-2.4-5.11 adl.; Inc. 58,1 adl.; Sd 24,1-2 adl.; Sd 67,1-2 adl.; Sd 139; Sd 346,1-2 adl.; Sd 500,1-2 adl.; Sd 501; Sd 551,1-2 adl.; Sd 557,1 adl.; Sd 588; Sd 589; Sd 590,1-2 adl.; Sd 591; Sd 605; Sd 619a,1-2 adl.; Sd 623; Sd 624; Sd 625; Sd 638; Sd 707,1-3 adl,; Sd 867,2 adl.; Sd 870; Sd 877,1-2 adl.; Sd 878; Sd 940; Sd 945,1-2 adl.; Sd 946; Sd 963; Sd 1176,1-2 adl.; Sd 1186,1-3 adl.; Sd 1210; II-3206/1; De 209; De 216,3 adl.; De 227/1; De 227/2; De 332,1-2 adl.; De 394,3 adl.; De 416,1-2 adl.; De 578; De 582; De 625; De 702,1 adl.; De 709; De 802,1-2 adl.; De 861; De 866,2 adl.; De 883; De 896; De 942; De 948,1-3 adl.; De 1008; De 1071; De 1074; Dp 269,9 adl.; Fb 76,1; $\mathrm{Fb} 76,2 ; \mathrm{Fb} 76,3 ; \mathrm{Fb} 76,4 ; \mathrm{Fb} 76,5 ; \mathrm{Fb} 76,6 ; \mathrm{Fb} 76,7 ; \mathrm{Fb}$ 103,2-3 adl.; Fb 107; Lg 178; Lg 255; Lg 712; XVI D 15; XVI F 38,2 adl.; XVI F 46; XVI O 90,1 adl.

${ }^{17}$ Gwioździk, Różycki, Druki XVI wieku, s. 56-57.

${ }^{18}$ Sd 129; Sd 144,1-3 adl.; Sd 358; Sd 435; Sd 471,1-3 adl.; Sd 481; Sd 507; Sd 510; Sd 561,1 adl.; Sd 571; Sd 622,1 adl.; Sd 631; Sd 631a; Sd 864; Sd 880,2-3 adl.; Sd 886; Sd 1202; Sd 1303,1-2 adl.; Sd 1331; II-3043; II-3173; De 218,1-3 adl.; De 324,2 adl.; De 515,1-2 adl.; De 569a; De 569b; De 671; De 723; De 833; De 837,2 adl.; Fb 113,3 adl.; Fb 374; Fb 3072; Tm 154; XVI D 115,1-3 adl.; XVI D 146; XVI F 5; XVI O 9; XVI O 61; XVI O 62; XVI O 94,2 adl.; XVI O 135.

${ }^{19}$ Gwioździk, Różycki, Druki XVI wieku, s. 58.

${ }^{20}$ Sd 55,1-2 adl.; Sd 432,1-3 adl.; Sd 480; Sd 702; Sd 873; Sd 941; Sd 953; Sd 964; Sd 978; Sd 1213,1-2 adl.; II-3115/1; II-315/2; II-3115/3; II-3116; III-N 1/I; III-N 1/II; De 135,2 adl.; De 238,1-2 adl.; De 432; ; De 492,1-4 adl.; De 573,1 adl.; De 631; De 638; De 641,2 adl.; De 644; De 659,1-2 adl.; De 667,1-2 adl.; De 678; De 679,1-2 adl.; De 692; De 698; De 699,1-2 adl.; De 707; De 713,12 adl.; De 825,2 adl.; De 869,1 adl.; Dp 41,2-4 adl.; Dp 45; Dp 60; Dp 98,2 adl.; Dp 121; Dp 151; Dp 339,1-2 adl.; Dp 339a,1-2 adl.; Dp 371,1-2 adl.; Fb 375; Fb 698,1-3 adl.; Fb 3053,1-2 adl.; Lg 581,1-2 adl.; XVI D 14; XVI F 129,1-3 adl.; XVI O 88; XVI O 145,2 adl. 
skim, dzieła ojców Kościoła, zwłaszcza św. Augustyna ${ }^{21}$. W zbiorach Biblioteki „Hosianum” znajduje się 51 dzieł wydanych w tej oficynie ${ }^{22}$.

W XVI wieku dominującym ośrodkiem typograficznym w Polsce był Kraków. Tamtejsze oficyny wpływały na rozwój piśmiennictwa w języku narodowym, wydając m.in. literaturę naukową, teologiczną i polemiczną, a także druki urzędowe, liturgiczne i literaturęe ${ }^{23}$.

Drukarnia Łazarza Andrysowica ( $† 1577$ r.) służyła potrzebom kontrreformatorów ${ }^{24}$. Z oficyny wyszło 17 warmińskich druków z XVI wieku, w tym trzy mszały warmińskie, konstytucje sejmowe z 1588 i 1596 roku oraz dzieła teologiczne $^{25}$.

W drukarni Szarffenbergów podejmowano się wydawania dzieł z różnych dyscyplin naukowych i teologicznych. Drukowano tam prace medyczne, prawnicze, astronomiczne, urzędowe, podręczniki i literaturę piękną ${ }^{26}$. Oficyna ta wydała 16 dzieł z XVI wieku znajdujących się w Bibliotece „Hosianum”, m.in. Confessio fidei Stanisława Hozjusza, dwa egzemplarze Biblii Leopolity i Księgi sentencji Piotra Lombarda ${ }^{27}$.

Oficyna Andrzeja Piotrkowczyka (†1620 r.) oprócz literatury świeckiej, w dużej mierze była nastawiona na publikowanie piśmiennictwa religijnego, głównie z zakresu teologii polemicznej, ascetycznej, moralnej, hagiografii, kaznodziejstwa i biblistyki ${ }^{28}$. Z jego drukarni pochodzi sześć druków, a wśród nich księgi liturgiczne i dzieła teologiczne ${ }^{29}$.

Drukarnia Macieja Wirzbięty (†1605 r.) była przede wszystkim związana $\mathrm{z}$ ugrupowaniami reformacyjnymi ${ }^{30}$. Z tej oficyny pochodzą cztery warmińskie stare druki, w tym Legenda aurea Jakuba de Voragine oraz Postylle Mikołaja Reja i Grzegorza z Żarnowca ${ }^{31}$.

Inny drukarz tego okresu, Florian Ungler (†1536 r.), zajmował się wydawaniem popularnej literatury pięknej, okolicznościowej, dewocyjnej, kalendarzy,

${ }^{21}$ Clair, A History of European Printing, s. 88-89; Gwioździk, Różycki, Druki XVI wieku, s. $62-63$.

${ }^{22}$ Sd 125; Sd 145; Sd 210; Sd 344; Sd 348; Sd 564; Sd 565; Sd 566; Sd 593; Sd 703,2 adl.; Sd 708; Sd 709,2 adl.; Sd 724; Sd 734,1-2 adl.; Sd 819; Sd 820/VIII; Sd 850,1-5 adl.; Sd 867,1 adl.; Sd 894; Sd 912; Sd 914/b,1-3 adl.; Sd 922/I,1-2 adl.; Sd 931; Sd 955; Sd 956; Sd 1238,3 adl.; De 1038; Ea 51,2 adl.; Fb 103,4 adl.; Fb 105,2 adl.; Fb 183; XVI F 3; XVI F 6; XVI F 23; XVI F 24; XVI F 25; XVI F 26; XVI F 29; XVI F 36; XVI F 45,1 adl.; XVI F 108; XVI F 110; XVI F 126.

${ }^{23}$ Drukarze dawnej Polski od XV do XVIII wieku, t. 1: Małopolska, cz. 1: Wiek XV-XVI, oprac.

A. Kawecka-Gryczowa, Wrocław-Warszawa-Kraków-Gdańsk-Łódź 1983, s. 105-115.

${ }^{24}$ Tamże, s. 69-99. 125-137.

${ }^{25}$ Sd 643; Sd 643c; Sd 814; De 679,3 adl.; Dp 218,1 adl.; Dp 246,3 adl.; Dp 269,7 adl.; Dp 277; Dp 294,1.5 adl.; Dp 309; Dp 346; Dp 363,1-3 adl; Dp 406; Fb 6,8 adl.

${ }^{26}$ Drukarze dawnej Polski, s. 231-297.

${ }^{27}$ De 270,1-4 adl.; Dp 50,4 adl.; Dp 65,3 adl.; Dp 98,3 adl.; Dp 135,5 adl.; Dp 215; Dp 232,4 adl.; Dp 260,1 adl.; Dp 294,3 adl.; Dp 374; XVI F 1; XVI F 33.

${ }^{28}$ Drukarze dawnej Polski, s. 147-169.

${ }^{29}$ Dp 98,1 adl.; Dp 246,1 adl.; Dp 362,2 adl.; XVI F 34; XVI F 156; XVI 157.

${ }^{30}$ Gwioździk, Różycki, Druki XVI wieku, s. 78.

${ }^{31}$ Dp 71,3 adl.; Dp 310; II 1 F 9; XVI Q 4. 
podręczników, rubryceli, a także tekstów prawniczych ${ }^{32}$. Z tej drukarni pochodzą trzy druki z XVI wieku w zbiorach Biblioteki „Hosianum”33.

\section{Wlaściciele druków z XVI wieku}

Szesnastowieczne druki warmińskie przechodziły przez lata z rąk do rąk. Nie sposób skomentować wszystkich proweniencji. Najczęściej własność zaznaczano za pomocą własnoręcznych wpisów, ale część ksiąg posiada superekslibrisy, ekslibrisy i pieczęcie. Z bardziej znanych właścicieli, których znaki lub wpisy proweniencyjne można zidentyfikować, należy wymienić: bpa Jana Dantyszka ${ }^{34}$, kardynała Stanisława Hozjusza ${ }^{35}$, bpa Marcina Kromera ${ }^{36}$, bpa Szymona Rudnickiego ${ }^{37}$, kardynała Andrzeja Batorego ${ }^{38}$ czy króla pruskiego Fryderyka Wilhelma ${ }^{39}$.

\section{Zawartość treściowa i autorzy}

W szesnastowiecznym księgozbiorze Biblioteki „Hosianum” reprezentowani są pisarze starożytni (25 starych druków). Można w nim znaleźć: bajki Ezopa (VI

${ }^{32}$ Drukarze dawnej Polski, s. 299-325.

${ }^{33}$ Dp 65,2 adl.; Dp 68,2-3 adl.

${ }^{34}$ Żył w latach 1485-1548. W kancelarii Zygmunta I zajmował się sprawami pruskimi. Był znakomitym dyplomatą i poetą. W 1529 r. został kanonikiem warmińskim, w 1530 r. - biskupem chełmińskim, w 1537 r. - biskupem warmińskim - zob. Poczet biskupów warmińskich, s. 123-134. Druki z jego znakami proweniencyjnymi: Inc. 58; Sd 57,1-3 adl.; Sd 405,1-3 adl.; Sd 608; Sd 615,12 adl.; Sd 866,1-2 adl.

${ }^{35}$ Żył w latach 1504-1579. W 1549 r. został biskupem chełmińskim, w 1551 r. - biskupem warmińskim, w 1560 r. był nuncjuszem apostolskim w Wiedniu, od 1561 r. - kardynałem, w 1562 r. - legatem papieskim na Sobór Trydencki. W 1565 r. założył Warmińskie Seminarium Duchowne w Braniewie - zob. Poczet biskupów warmińskich, s. 149-168. Druk z jego znakiem proweniencyjnym: Sd 1180.

${ }^{36}$ Żył w latach 1512-1589. Był doktorem obojga praw. Jako sekretarz królewski zajmował się sprawami pruskimi. W 1542 r. przyjął święcenia kapłańskie. Był proboszczem w Bieczu, kanonikiem kieleckim i krakowskim, a od 1551 r. - kanonikiem warmińskim. W 1570 r. został koadiutorem kardynała Stanisława Hozjusza. W 1579 r. został biskupem warmińskim. Walczył z Reformacją, wydał warmińskie księgi liturgiczne, napisał historię Polski - zob. Poczet biskupów warmińskich, s. 169-182. Druki z jego znakami proweniencyjnymi: Sd 126; Sd 129; Sd 596; De 569a; De 866; Dp 164; Dp 309; Dp 339; II-3115/1-3; Fb 6,1-10 adl.

37 Żył w latach 1552-1621. Był sekretarzem wielkim koronnym, dyplomatą, kanonikiem krakowskim i poznańskim, a od 1604 r. - kanonikiem warmińskim. W 1605 r. został biskupem warmińskim, a w 1617 r. - administratorem apostolskim diecezji sambijskiej. Wydał brewiarz, mszał i dwie agendy warmińskie - zob. Poczet biskupów warmińskich, s. 203-222. Druki z jego znakami proweniencyjnymi: Sd 1175,1-8 adl.

${ }^{38}$ Żył w latach 1563-1599. Był bratankiem Stefana Batorego. W 1581 r. został kanonikiem warmińskim, w 1584 r. - kardynałem, w 1589 r. - biskupem warmińskim - zob. Poczet biskupów warmińskich, s. 183-192. Druki z jego znakami proweniencyjnymi: Sd 631a; De 400; Fb 183; XVI O 88.

39 Żył w latach 1688-1740, od 1713 był królem Prus i twórcą militarnej potęgi Prus. Druki z jego znakami proweniencyjnymi: Inc. 114,1-2 adl.; Sd 49,1-2 adl.; Sd 138,1-2 adl.; Sd 1190,1-12 adl.; H 2166; XVI Q 96. 
w. p.n.e. $)^{40}$, dzieła filozoficzne Cicerona (106-43 p.n.e. ${ }^{41}$, Filona z Aleksandrii $(10 \text { p.n.e.- } 40)^{42}$, Plutarcha (ok. 50 -ok. 125$)^{43}$, listy i dzieło o sztuce poezji Horacego (65-8 p.n.e) ${ }^{44}$, poezje Owidiusza (43 p.n.e.-17/18) ${ }^{45}$, dzieła historyków rzymskich Tytusa Liwiusza (59 p.n.e.-17) ${ }^{46}$ i Tacyta (ok. 55-120) ${ }^{47}$ oraz historyka żydowskiego Józefa Flawiusza (37-94) ${ }^{48}$, dzieła mówcy ateńskiego Izokratesa (436338 p.n.e. ${ }^{49}$, pisarza i retora rzymskiego Swetoniusza (ok. $\left.69-130\right)^{50}$, a nawet dzieło ojca medycyny - Hipokratesa (ok. 460-ok. 370 p.n.e. $)^{51}$.

Zasadniczą część szesnastowiecznego piśmiennictwa Biblioteki „Hosianum” tworzą dzieła religijne. Okres patrystyczny jest reprezentowany przez dzieła: Tertuliana (ok. 150/160-240) ${ }^{52}$, Orygenesa (ok. 185-254) (53 $^{53}$. Cypriana (ok. 200/210$258)^{54}$, św. Atanazego (ok. 295-373) ${ }^{55}$, św. Grzegorza z Nazjanzu (330-390) $)^{56}$, św. Grzegorza z Nyssy (ok. 335-394/395) $)^{57}$, św. Ambrożego (ok. 339-397) ${ }^{58}$, św. Hieronima (347-420) ${ }^{59}$, św. Jana Chryzostoma (ok. 350-407) $)^{60}$, św. Augustyna (354430) ${ }^{61}$, św. Cyryla Aleksandryjskiego (378-444) ${ }^{62}$, Teodoreta z Cyru (ok. 386/393ok. 457/466) (33 $^{6}$ Kasjodora (ok. 485-583) ${ }^{64}$, św. Grzegorza I Wielkiego (ok. 540-

\footnotetext{
${ }^{40}$ XVI D 115,4 adl.

${ }^{41}$ Sd 871,1 adl; Sd 871,2 ald; Sd 1033; II-3205; XVI O 140; XVI O 142; XVI Q 132,3 adl.

${ }^{42}$ XVI F 45,2 adl.

${ }^{43} \mathrm{Sd} 1207$.

${ }^{44} \mathrm{Sd} 1175,3$ adl; XVI Q 132,4 adl.

${ }^{45}$ Sd 1175,2 adl; Sd 1175,5 adl; II-3051,3 adl.

${ }^{46} \mathrm{Sd} 4$.

${ }^{47}$ Sd 974,1 adl; XVI S 154.

${ }^{48}$ Sd 606,1 adl; Sd 606,2 adl; Sd 606,3 adl; Sd 955.

${ }^{49} \mathrm{Sd} 704,2$ adl.

${ }^{50} \mathrm{Sd} 1190,5$ adl; Sd 1190,6 adl.

${ }^{51} \mathrm{Sd} 1190,8$ adl.

${ }^{52}$ Sd 1322; De 833; XVI F 36.

${ }^{53}$ Sd 931; XVI F 40.

${ }^{54} \mathrm{Sd}$ 145; Sd 703,1 adl; XVI F 0136.

${ }^{55} \mathrm{Sd} 259$; Sd 862; XVI F 45,1 adl.

${ }^{56} \mathrm{Sd} 863$.

${ }^{57} \mathrm{Sd} 831$.

${ }^{58}$ Sd 850,1 adl; Sd 850,2 adl; Sd 850,3 adl; Sd 850,4 adl; Sd 850,5 adl; De 702,1 adl.

${ }^{59}$ Sd 344; Sd 348; Sd 819; Sd 914,1 adl; Sd 914,2 adl; Sd 914/a; Sd 914/b,1 adl; Sd 914/b,2 adl;
} Sd 914/b,3 adl; Sd 944; Ok 2.

${ }^{60}$ Sd 932; Sd 633; Sd 903,1 adl; Sd 903,2 adl; Sd 922/1,1 adl; Sd 922/1,2 adl; Sd 922/2,1 adl; Sd 922/2,2 adl; Ok 36; II-3136/1; II-3136/2; II-3136/3; XVI F 45,1 adl; XVI O 56.

${ }^{61}$ Inc. 1,3 adl; Sd 345,1; Sd 345,2; Sd 345,3; Sd 345,6; Sd 345,7; Sd 345,8; Sd 345,10; Sd 820,8; Sd 912; Sd 950,1 adl; Sd 950,2 adl; Sd 950,3 adl; Sd 956; XVI F 6; XVI F 23; XVI F 24; XVI F 25; XVI F 26; XVI F 29; XVI F 38,1 adl; XVI F 44,1 adl; XVI F 44,2 adl; XVI F 44,3 adl; XVI F 110; XVI F 112; XVI F 126; XVI F 127.

${ }^{62}$ Sd 910,1 adl; Sd 910,2 adl; Sd 910,3 adl; Sd 910,4 adl; Sd 910,5 adl; XVI O 67,3 adl.

${ }^{63}$ Sd 631a; Sd 886; Sd 917; XVI O 9; XVI O 67,3 adl; XVI Q 138.

${ }^{64} \mathrm{Fb} 1392,2$ adl. 
$604)^{65}$, św. Izydora z Sewilli (ok. 560-636) ${ }^{66}$, św. Leona I Wielkiego (ok. 390$461)^{67}$.

Teologia okresu średniowiecza jest reprezentowana w księgozbiorze z XVI wieku Biblioteki „Hosianum” przez dzieła m.in.: św. Anzelma z Canterbury (1033-1109) ${ }^{68}$, św. Bernarda z Clairvaux (1090-1153) ${ }^{69}$, Piotra Lombarda (ok. 1100-ok. 1160/1164) $)^{70}$, św. Alberta Wielkiego (1193-1280) ${ }^{71}$, św. Bonawentury (ok. 1217-1274) ${ }^{72}$, św. Tomasza z Akwinu (1225-1274) ${ }^{73}$, Mikołaja z Liry (ok. 1270-ok. 1340) ${ }^{74}$, św. Antonina z Florencji (1389-1459) ${ }^{75}$.

Teologia katolicka z okresu kontrreformacji przybrała kształt polemiczny, by przeciwstawić się reformacji. Wśród druków z XVI wieku Biblioteki „Hosianum” dzieła z tego okresu są najliczniejsze. Są to zarówno dzieła reformatorów: Erazma z Rotterdamu (1466/7-1536) ${ }^{76}$, Marcina Lutra (1483-1546) ${ }^{77}$, Filipa Melanchtona $(1497-1560)^{78}$, Jana Kalwina (1509-1564) ${ }^{79}$, Jana Bugenhagena (1485-1558) $)^{80}$, jak i kontrreformatorów: św. Jana Fishera (1469-1535) ${ }^{81}$, Jana Ecka (1486-1543) ${ }^{82}$, Piotra Soto $(1495 / 1500-1563)^{83}$, Melchiora Cano (1509-1560) ${ }^{84}$ czy św. Roberta

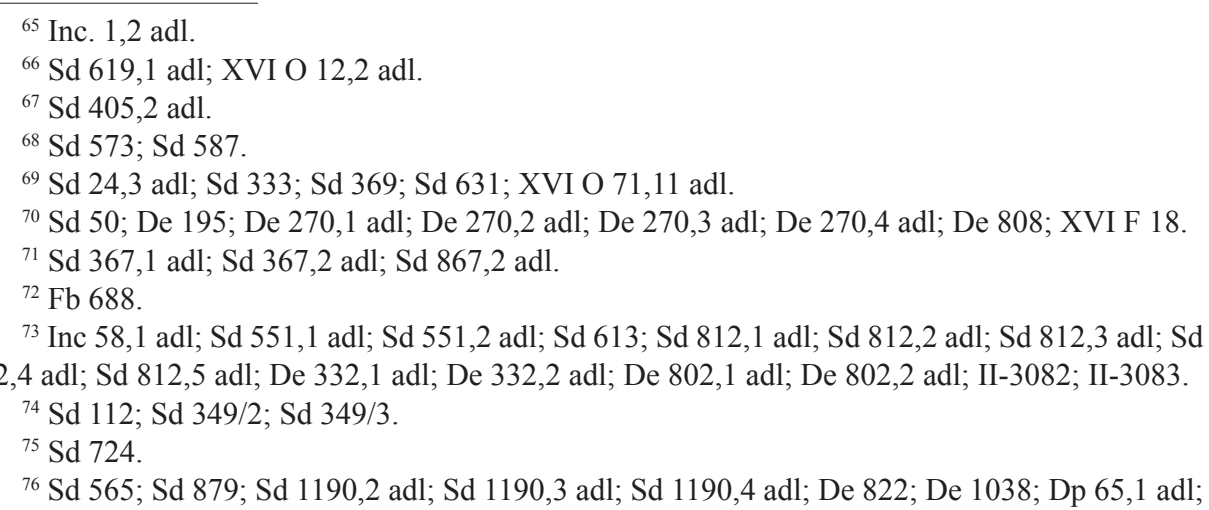
Dp 135,1 adl; Dp 135,3 adl; Dp 135,4 adl; Dp 135,5 adl; Dp 135,6 adl; Tm 157; XVI Q 52,1 adl; XVI Q 52,2 adl.

${ }^{77}$ Sd 53; Sd 353/2; Sd 353/3; Sd 406,2 adl; Sd 406,3 adl; Sd 406,4 adl; Sd 406,5 adl; Sd 406,6 adl; Sd 406,7 adl; Sd 717,1 adl; Sd 717,2 adl; Sd 949; De 2073,I; De 2073,II; De 2073,III; De 2073,V; De 2073,VII; De 2073,VIII,1 adl; XVI O 71,8 adl; XVI O 71,10 adl; XVI O 118; XVI O 143; XVI Q 97,1 adl; XVI Q 97,2 adl; XVI Q 97,3 adl; XVI Q 97,4 adl; XVI Q 97,5; XVI Q 97,6 adl; XVI Q 97,7 adl; XVI Q 97,8 adl; XVI Q 97,9 adl; XVI Q 97,10 adl; XVI Q 104,1 adl; XVI Q 104,2 adl; XVI Q 104,3 adl; XVI Q 104,4 adl; XVI Q 104,5 adl; XVI Q 104,6 adl; XVI Q 104,8 adl; XVI Q 104,9 adl; XVI Q 104,10 adl.

${ }^{78}$ Sd 406,8 adl; Sd 483; De 219; De 559; De 559a; De 591,1 adl; De 591,2 adl; De 704,2 adl; Fb 3056; XVI O 71,2 adl; XVI O 71,4 adl; XVI O 71,5 adl; XVI O 71,6 adl; XVI O 71,7 adl; XVI O 71,8 adl; XVI Q 104,10 adl; XVI Q 106,39 adl; XVI Q 106,50 adl.

${ }^{79}$ Sd 350; De 585,3 adl; XVI O 67,1 adl; XVI Q 50.

${ }^{80}$ De 880,5 adl.

${ }^{81}$ Sd 557,1 adl; De 216,3 adl; De 578; De 683.

${ }^{82}$ Sd 54,1 adl; Sd 54,2 adl; Sd 370,2 adl; Sd 406,7 adl; Sd 557,2 adl; De 750; De 1067,1 adl; De 1067,2 adl; Dp 65,4 adl; XVI O 57,1 adl.

${ }^{83}$ De 562,1-2 adl; XVI D 014.

${ }^{84}$ De 569-a; De 569-b. 
Bellarmina (1542-1621) ${ }^{85}$. Za prawdziwego „bojownika” katolickiego uznawano Johannesa Cochlaeusa (1479-1552) ${ }^{86}$, który poświęcił majątek i zdolności na zwalczanie luteran. Publikował nie tylko swoje prace, ale i wydawał dzieła innych polemistów ${ }^{87}$. Dwa woluminy to dzieła św. Tomasza Morusa (1478-1535), ściętego za nieuznanie Henryka VIII głową Kościoła w Anglii ${ }^{88}$. Przy okazji warto zaznaczyć, że autorem najliczniej reprezentowanym w szesnastowiecznym księgozbiorze Biblioteki „Hosianum” jest Marcin Luter (41 dzieł).

Bogato reprezentowane są księgi autorów pochodzących z Towarzystwa Jezusowego: św. Piotra Kanizjusza (1521-1597) ${ }^{89}$, Franciszka Suareza (1548-1617) ${ }^{90}$ i innych - bardziej lub mniej znanych. Szesnaście pozycji to dzieła Ludwika z Grenady (1505-1588) - bardzo popularnego szesnastowiecznego mistyka dominikańskiego ${ }^{91}$.

Są dzieła wybitnych biskupów warmińskich, którzy piastowali również inne ważne funkcje, zarówno kościelne, jak i państwowe: Jana Dantyszka $(1485-1548)^{92}$, Stanisława Hozjusza (1505-1579) ${ }^{93}$, Marcina Kromera (1512$1589)^{94}$. Reprezentowane są prace rodzimych autorów - księży warmińskich, kanoników i jezuitów pracujących w Braniewie: Jana Benedykta Solfy ${ }^{95}$, Antoniego Possevino ${ }^{96}$, Tomasza Tretera ${ }^{97}$, Fabiana Kwadrantyna (Quadrantinu-

\footnotetext{
${ }^{85}$ Sd 1218; De 1252; XVI F 7,1-2; XVI F 32; XVI O 93.

${ }^{86}$ Sd 26,5 adl.; Sd 937; De 953; De 989; De 991; De 1008; Fb 117,1-2; Fb 774.

${ }^{87}$ J.L. Illanes, J.I. Saranyana, Historia teologii, Kraków 1997, s. 186-187.

${ }^{88} \mathrm{Fb} 105,1$ adl; XVI O 064.

${ }^{89}$ Sd 395; De 269; De 269 bis; K 31.

${ }^{90} \mathrm{Sd} 801 ; \mathrm{Sd} 802$.

${ }^{91}$ Sd 500,1-2 adl; Sd 501; Sd 1242,1-2 adl; Sd 1351; Sd 1351 bis; De 896; II-3106/1-2; II3135/1-2; XVI D 015; XVI O 013; XVI O 081; XVI O 0151.

${ }^{92} \mathrm{Dp} 50,2$ adl.

${ }^{93}$ Sd 640; De 573,1 adl; De 1965; Dp 45; Dp 150; Dp 215; Dp 231; Dp 295; Dp 307; Dp 325;
} Dp 339,1 adl; Dp 339,2 adl; Dp 339a,1 adl; Dp 339a,2 adl; Dp 340; Dp 371,1 adl; Dp 371,2 adl; III-N 1/I; III-N 1/II; XVI O 88.

${ }^{94}$ Sd 129; Sd 596; De 573,6 adl; Dp 41,4 adl; Dp 151; Dp 216.

${ }^{95}$ Żył w latach 1483-1564, studiował w Krakowie, Padwie i Bolonii, doktor medycyny i obojga praw, był lekarzem nadwornym Zygmunta I Starego i Zygmunta II Augusta, od 1526 r. był kanonikiem warmińskim, a od 1547 r. - prepozytem. Był autorem podręczników lekarskich, prac historycznych i wierszy - zob. A. Kopiczko, Duchowieństwo katolickie diecezji warmińskiej, s. 309. Jego prace w zbiorach Biblioteki „Hosianum”: Dp 50,5 adl.; Dp 363,2 adl.

${ }^{96}$ Żył w latach 1533/1534-1611: jezuita, pedagog, dyplomata. Studiował w Rzymie, założył Alumnat Papieski w Braniewie i seminaria duchowne w Wilnie, Rydze, Ołomuńcu, Klausenburgu. Pisał dzieła przeciwko różnowiercom - zob. Wielka Encyklopedia PWN, red. J. Wojnowski, t. 22, Warszawa 2004, s. 118. Jego dzieła w zbiorach Biblioteki „Hosianum”: De 631a,2 adl.; De 695; De 727; Dp 133; Dp 311; Dp 336; Dp 336b; XVI O 59.

${ }^{97}$ Żył w latach 1547-1610: poeta, filolog, doktor praw, rytownik, tłumacz. Uczył się w Poznaniu, u jezuitów w Braniewie, w Rzymie. Sprowadził go kard. Stanisław Hozjusz. Po jego śmierci od 1579 r. pozostawał w służbie kard. Andrzeja Batorego. Był kanonikiem, kustoszem i kanclerzem Warmińskiej Kapituły Katedralnej. W grafice był uczniem G.B. Cavallierego. Sam ilustrował swe dzieła. Najważniejszą jego pracą jest biografia kard. Stanisława Hozjusza, składająca się ze 
sa $)^{98}$, Fryderyka Bartscha ${ }^{99}$. Są wiersze pierwszego poety humanistycznego, urodzonego na Warmii, Eustachego Knobelsdorfa ${ }^{100}$. Znaleźć można również dzieła innych znanych polskich autorów, z których warto wymienić: Andrzeja Frycza Modrzewskiego (1503-1572) ${ }^{101}$, Mikołaja Reja (1505-1569) ${ }^{102}$, Jakuba Górskiego (ok. 1525-1585) ${ }^{103}$ - rektora Uniwersytetu Krakowskiego, ks. Piotra Skargę (1536-1612) ${ }^{104}$, Stanisława Reszkę (1544-1600) ${ }^{105}$.

W szesnastowiecznym księgozbiorze Biblioteki „Hosianum” nie mogło zabraknąć wielu wydań Biblii (26) ${ }^{106}$, ksiąg liturgicznych (wśród nich mszały i agendy warmińskie oraz agenda krakowska z 1517 roku), martyrologiów, kazań, kodeksów prawa cywilnego i kanonicznego. Są dzieła poety Franciszka Petrarki (1304-1374) ${ }^{107}$, dzieła z dziedziny filozofii, retoryki, historii, literatury, astronomii, biologii, medycyny, ekonomii, geografii, a wśród nich dzieła wybitnego kartografa na dworze hiszpańskim - Abrahama Orteliusa $(1527-1598)^{108}$.

100 miedziorytów przedstawiających sceny z życia Hozjusza - zob. Kopiczko, Duchowieństwo katolickie diecezji warmińskiej, s. 333-334. Jego praca w zbiorach Biblioteki „Hosianum”: Fb 631.

${ }^{98}$ Żył w latach 1549-1605: jezuita, uczeń jezuickiego gimnazjum w Braniewie. Był kapelanem Marcina Kromera i kanonikiem w Dobrym Mieście, proboszczem w Reszlu i Parnawie, był kaznodzieją w Krakowie i w Rydze, mistrzem nowicjatu w Rydze w latach 1591-1595, prefektem seminarium w Braniewie w latach 1598-1597, pozostawał w służbie dworu królewskiego w latach 1597-1600, był działaczem kontrreformacyjnym w Braniewie i wybitnym znawcą pism św. Ignacego Loyoli - zob. Kopiczko, Duchowieństwo katolickie diecezji warmińskiej, s. 181. Jego praca w zbiorach Biblioteki „Hosianum”: XVI O 145,2 adl.

${ }^{99}$ Żył w latach 1552-1609, urodził się w Braniewie, wstąpił do jezuitów w Rzymie, studiował filozofię w Rzymie, teologię w Wiedniu, potem powrócił do Polski i kierował w Braniewie seminarium warmińskim, alumnatem papieskim i konwiktem szlacheckim, był rektorem w Braniewie w latach 1584-1590 i Wilnie w latach 1592-1595, potem superiorem i kaznodzieją w Gdańsku w latach 1595-1598, wiceprowincjałem dla litewskiej części prowincji polskiej od 1598 r., spowiednikiem Zygmunta III Wazy od $1600 \mathrm{r}$. Zmarł na zarazę, opiekując się chorymi żołnierzami - zob. Encyklopedia wiedzy o jezuitach na ziemiach Polski i Litwy 1564-1995, s. 30. Jego praca w zbiorach Biblioteki „Hosianum”: Dp 246,1 adl.

${ }^{100}$ Żył w latach 1519-1571. Urodzony w Lidzbarku Warmińskim. Był stypendystą biskupa Jana Dantyszka, uczył się w Lidzbarku i Chełmnie, studiował we Frankfurcie nad Odrą, Wittenberdze, Lipsku, Lowanium, Paryżu i Orleanie. Był kanonikiem warmińskim, kustoszem, wyświęconym na kapłana w 1553 r. Podczas nieobecności Stanisława Hozjusza był administratorem diecezji. Pisał teksty łacińskie. Wzorce czerpał z Owidiusza - zob. Kopiczko, Duchowieństwo katolickie diecezji warmińskiej, s. 152-153. Jego dzieło w zbiorach Biblioteki „Hosianum”: Dp 246,4 adl.

${ }^{101}$ Dp 269,1 adl.

${ }^{102}$ Dp 310.

${ }^{103}$ Sd 432,1-3 adl; De 644; De 659,2 adl; De 707; Dp 60.

${ }^{104}$ Dp 117; Dp 247.

${ }^{105} \mathrm{Sd} 38 ; \mathrm{Dp} 283 ; \mathrm{Fb} 1004$.

${ }^{106}$ Sd 123; Sd 408; Sd 409,1 adl; Sd 427; Sd 428; Sd 469; Sd 526; Sd 542; Sd 564; Sd 566; Sd 585; Sd 586; Sd 607; Sd 625; Sd 635,1 adl; Sd 635,2 adl; Sd 638; Sd 716; Sd 1198; Dp 65,2 adl; Dp 227; XVI F 1; XVI F 33; XVI F 109; XVI O 73; XVI V 123.

${ }^{107} \mathrm{Sd} 517$.

${ }^{108}$ XVI F 117,1-2 adl; XVI Q 103. 


\section{Różnorodność językowa}

Większość starych druków z XVI wieku ze zbiorów Biblioteki Warmińskiego Seminarium Duchownego „Hosianum” została napisana w języku łacińskim (1318, co stanowi 84,54\%). Wśród nich kilka - przede wszystkim słowników lub leksykonów - oprócz łaciny zawiera język grecki bądź hebrajski.

Reprezentowane są również inne języki: niemiecki (200), polski (20), francuski (11), włoski (6), angielski (2), niderlandzki (1), a nawet czeski (1).

\subsection{Druki w języku polskim}

Wśród starych druków z XVI wieku w zbiorach Biblioteki „Hosianum” w Olsztynie znajduje się 20 druków napisanych w języku polskim.

Są to dwa egzemplarze Biblii Leopolity ${ }^{109}$. Zostały wydrukowane w 1561 roku w Krakowie, w oficynie Mikołaja i Stanisława Szarffenbergów. Oprawa pierwszego z nich, o sygnaturze XVI F 01, pochodzi z XIX wieku. Jest to tektura obleczona jasnobrązową skórą, na której znajduje się ślepy wytłok liniowy, plecionkowy i gwiazdkowy. Na grzbiecie znajduje się złocony napis: BIBLIA TO IEST KXIEGI Stharego y Nowego ZAKONU 1561. Obcięcia kart są barwione na żółto, nakrapiane czerwienią ${ }^{110}$. W drugim egzemplarzu, o sygnaturze XVI F 033, występuje defekt: brak kart $\mathrm{A}_{1-2}$, a karty: $\mathrm{YY}_{1}, \mathrm{YY}_{3}, \mathrm{YY}_{4}$ są uzupełnione ręcznie. Oprawa pochodzi z XVI wieku. Są to deski bukowe obleczone świńską skórą, na której znajduje się ślepy wytłok liniowy i plecionkowy. Na przedniej okładce znajduje się monogram IHS i napis: BIBLIA SWIETA STAREGO Y NOWEGO ZAKONV, na tylnej okładce widnieje monogram MARIA. Pozostały ślady zapinek. Obcięcia kart barwione są na żółto, nakrapiane czerwienią.

Wśród polskich druków z XVI wieku są także dwa wydania postylli, czyli komentarzy do Pisma Świętego o charakterze egzegezy lub też zbiorów kazań komentujących fragmenty Biblii. Były one szczególnie rozpowszechnione w czasach reformacji. Jest to: Grzegorz z Żarnowca: Postylla, część I-II, s. 1. t. a. [Kraków, Maciej Wirzbięta, 1580], sygnatura II 1 F 9. Druk posiada oprawę wtórną (z XIX wieku), z przyciętymi marginaliami. Jest to półskórek i papier introligator-

${ }^{109}$ Biblia Leopolity (1561) - pierwszy drukowany polski przekład całej Biblii. Tłumaczono z Wulgaty na zlecenie rodziny Szarffenbergów, autorem przekładu był ks. Jan Nicz ze Lwowa (pseudonim Leopolita = Lwowianin), wykładowca m.in. Uniwersytetu Jagiellońskiego w Krakowie. Przekład ten jest też znany jako Biblia Szarffenbergowska (jako że przekładu dokonano na zlecenie Marka i jego syna Stanisława Szarffenbergów). Przekład dedykowano Zygmuntowi Augustowi.

${ }^{110}$ Tekst z karty tytułowej: Biblia To iest Kxięgi Stharego y Nowego Zakonu, na Polski ięzyk, z pilnością według Łacińskiey Bibliey od Kośćioła Krześćiańskiego powssechnego przyjęthey, nowo wyłożona. Cum Gratia et Priuilegio Sacrae Regiae Maiestatis. W Krakowie. W Drukarni Szarffenbergerow. 1561.> <Roku Panskiego Thysiącnego: Pięćsetnego, Sześćdziesiątnego y pierwssego, na zaiutrz po Nowym lećie. Naprzod ku ćći a ku chwale Panu Bogu w Troycy iedinemu, potym ku poćiessnemu y zbawiennemu vżywaniu wßysthkim wiernym zacnego narodu y ięzyka Polskiego, te Kxięgi Stharego y Nowego Zakonu, przed thym nigdy Polskim ięzykiem nie drukowane, ani widziane, theraz wykonane są w głownym mieśćie Polskim Krakowie, w Drukarni Mikołaia y Stanislawa Scharffenbergerow, ichże własnym nakładem. Z cżego bądź Panu Bogu wssechmogącemu cżeść, y chwała, y dzięk cżynienie na wieki wieczne. AMEN. MDLXI. 
ski. Obcięcia kart barwione są na czerwono. Ciekawszym drukiem, ze względu na znanego autora, jest: Mikołaj Rej: Postylla, Kraków, Maciej Wirzbięta, 1571, sygnatura Dp 310. Oprawa druku pochodzi z XVI wieku. Jest to tektura obleczona w gładką cielęcą skórę ze ślepym wytłokiem liniowym wokół obu okładek. Na grzbiecie znajduje się naklejka z XIX wieku: „Kazania”.

Literatura religijna jest reprezentowana przez dwa kazania Stanisława Grodzickiego: Kazanie na pogrzebie Katarzyny z Tęczyna Radziwitłowej, Wilno, Drukarnia Akademii Societatis Iesu, Daniel z Łęczycy, 1592, sygnatura Dp 195,4 adl. i $O$ czyśćcu kazanie wtóre, Wilno, Drukarnia Akademii Societatis Iesu, 1593, sygnatura $\mathrm{Dp} 195,5$ adl.

Nie mogło zabraknąć dzieł teologicznych w języku polskim. Jest ich siedem. Nie sposób rozpocząć ich prezentacji od dzieła Stanisława Hozjusza Cenzura albo rozsadek, s. 1. t. 1569, sygnatura Dp 150. Druk posiada pieczątki: „Bibliotheca Lycei Regii Hosiani” (XIX wiek) i „Bibliotheca Königlichen Lycei Hosiani Braunsberg" (XIX/XX wiek). Oprawa pochodzi z XVIII wieku. Jest to gładka świńska skóra. Pozostały ślady skórkowych związań. Na grzbiecie widnieje napis: „Censura abo Rozsądek wiary Katolickiej”.

Następne dzieło to: Jan Brencjusz: Catechismus, Królewiec, Jan Daubman, 1556, sygnatura Dp 359. Oprawa druku pochodzi z XVI wieku. Jest to tektura obleczona w brunatną skórę z linowym i roślinnym ślepym wytłokiem.

Kolejne dzieło to: Wojciech Emporyn: Ekscepcja przeciw apelacji Erazma Glicznera, Poznań, Dziedzice Jana Wolraba, 1600, sygnatura Dp 275,3 adl.

Autorem dwóch dzieł jest Adrian Iunga. Są to dwa wydania tego samego tytułu: Rozwiazanie pięćdziesiąt $i$ dwu kwestii o Kościele Bożym. Jedno zostało wydane w Poznaniu przez wdowę i dziedziców Jana Wolraba w 1593 (sygnatura Dp 263,1 adl. ${ }^{111}$, a drugie - w Krakowie, w drukarni Andrzeja Piotrkowczyka w 1599 (sygnatura Dp 362,2 adl.).

W końcu dwa dzieła są autorstwa Marcina Śmigleckiego. Jedno z nich to: Opisanie dysputy Nowogrodzkiej, Wilno, Wojciech Zajączkowski, 1594, sygnatura Dp 195,3 adl., a drugie to: O Bóstwie przedwiecznym Syna Bożego, Wilno, Drukarnia Akademii Societatis Iesu, 1595, sygnatura Dp 362,1 adl.

Sześć druków to dokumenty państwowe:

Dp 294,1 adl.: Konstytucje sejmu walnego koronacji królewskiej 1588, Kraków, Drukarnia Łazarzowa, 1588;

Dp 294,3 adl.: Konstytucje sejmu walnego warszawskiego 1589, Kraków, Mikołaj Szarffenbergier, 1589;

111 Tekst z karty tytułowej: Rozwiązanie Piąćidźiestąt y dwu QVAESTIY Ministrow Nowo=Ewangelickich, Jezuitom zadanych; O KOSCIELE BOZYM, WLASNOSCI, ZNAKACH Y NAVCE IEGO. Na DWIE cżęśći rozdźielone. W ktorych 156. znacżnieyßych Fałßszow, y potwarzy tychże Ministrow na Kośćoł święty Rzymski; y DAWNOSC prawdźiwey, a nigdy od czasow Apostolskich nieustawaiącey Wiary y Ceremoniy, tegoß Kośćioła świętego Rzymskiego, z pisma świętego podania Apostolskiego, Synodow y Doktorow starych Kościelnych, dowodnie się vkazuie. Przez Adriana Jungę Societatis IESV Theologa. Na końcu przydany ODPIS, na Ksiąßki iednego Ewangelika, przeciw Obrazom chrześćijańskim, tegoß Auctora. Regestr naprzodku, rzeczy przednieyßych, ktore się tu opisuią. Z dozwoleniem Starßych. $><$ W POZNANIV, U Wdowy y Dźiedźicow Jana Wolraba. Roku Pańskiego, 1593. 
Dp 294,5 adl.: Konstytucje sejmu walnego koronnego warszawskiego 1596, Kraków, Architypografia Łazarzowa, 1596;

Dp 195,1 adl.: Traktat różnych poselstw lubelskich i odprawa ich, Kraków, Jakub Siebeneicher, 1592;

Dp 294,2 adl.: Uniwersat poborowy roku 1588;

Dp 294,4 adl.: Uniwersat poborowy roku 1589.

I wreszcie jest jeden herbarz: Bartosz Paprocki: Herby Rycerstwa Polskiego, Kraków, Maciej Garwolczyk, 1584, sygnatura Dp 75v. Oprawa druku pochodzi z XVIII wieku. Jest to gładka świńska skóra. Obcięcia są barwione na czerwono. Na grzbiecie widnieje napis: „Paprocki Bartosz. Herby Rycerstwa Polskiego”. Druk pochodzi z Biblioteki Kolegiaty Dobromiejskiej.

\section{Oprawy}

Zabytkowe oprawy starych druków przechowywanych z zbiorach Biblioteki Wyższego Seminarium Duchownego Metropolii Warmińskiej „Hosianum” w Olsztynie mogą być ważnym źródłem do identyfikacji technik zdobniczych książki. Oczywiście dokładna analiza opraw druków szesnastowiecznych zdecydowanie wykracza poza ramy niniejszego opracowania. Wymaga bowiem bardziej wnikliwego przeprowadzenia specjalistycznych studiów i badan.

Należy jednak zauważyć, że druki z XVI wieku ze zbiorów wspomnianej biblioteki w dużej części charakteryzują się kunsztownymi oprawami. Są to oprawy charakterystyczne dla swojej epoki: deska dębowa lub bukowa, na którą naciągnięto brązową skórę cielęcą bądź białą świńską, ze ślepymi tłoczeniami i dekoracją wykonaną za pomocą radełka. Niektóre plakiety są pokryte złotem. Oprawy tego typu najczęściej były zamykane na mosiężne klamry. Znacznie rzadziej niż w inkunabułach można znaleźć na nich metalowe okucia z mosiądzu. Niewątpliwą ozdobą kilku opraw są metalowe guzy rozmieszczone w narożach oraz pośrodku obu okładzin. Niektóre z okuć i guzów odpadły, głównie na skutek ich wielokrotnego przemieszczania z miejsca na miejsce, ale być może część z nich została zdjęta przez bibliotekarzy w XIX wieku zgodnie z ówczesną praktyką ${ }^{112}$. Oprawy z białej, tłoczonej świńskiej skóry najczęściej spotyka się na dziełach dużych formatów. Są one charakterystyczne dla tzw. polskiego typu oprawy ${ }^{113}$. Niektóre druki posiadają superekslibrisy. Nazwa superekslibris wywodzi się z języka łacińskiego („,super” - na, nad, „ex libris” - z książek). Superekslibris jest znakiem własnościowym książki wytłoczonym lub wyrytym w oprawie skórzanej, na frontowej okładce. Posiadaczami superekslibrisów byli ludzie bardzo zamożni, zwykle królowie, magnaci i duchowni, którzy mogli sobie pozwolić na kosztowne i luksusowe oprawy. Tematem superekslibrisów był herb lub inicjał właściciela umieszczony centralnie w polu oprawy. Okres największej ich popularności przypadł na wiek XVI. W naszym przypadku cztery woluminy mają su-

${ }^{112}$ J. Tondel, Inkunabuly w zbiorach Biblioteki Wyższego Seminarium Duchownego w Pelplinie, Toruń-Pelplin 2007, s. 149.

113 W. Graczyk, J.M. Marszalska, Księgi rękopiśmienne i stare druki w zbiorach Biblioteki Wyższego Seminarium Duchownego w Płocku. Z dziejów kultury polskich bibliotek kościelnych w dawnych wiekach, Kraków 2010, s. 267. 
perekslibrisy bpa warmińskiego Jana Dantyszka ${ }^{114}$. Trzy z nich są pozłacane, a jeden posrebrzany. Ciekawostką jest, że superekslibris znajdujący się na oprawie druku Sd 405 jest odwrócony górą do dołu. Są również superekslibrisy bpa warmińskiego Marcina Kromera ${ }^{115}$ oraz dworu cesarskiego Habsburgów ${ }^{116}$.

Oprawy pergaminowe są wykonane z gładkiego naturalnego pergaminu (białe i żółte, ale są również barwione na zielono lub czerwono). Niektóre woluminy są oprawione w pergamin „,z odzysku”, pochodzący z graduałów bądź z innych rękopiśmiennych ksiąg kościelnych z notacją muzyczną. Pergamin zwykle był naciągany na wzmocnioną okładzinę tekturową. Przeważnie powierzchnia pergaminu jest gładka i nietłoczona, czasami zdarzają się delikatne elementy tłoczeń pozłacanych. Na grzbietach wielu opraw zachowały się informacje o autorze i tytule dzieła.

Do wykonania niektórych opraw używano tzw. półskórka, czyli tylko grzbiet książki jest obciągnięty skórą. Ten typ oprawy bywa nazywany oprawą mniszą.

Powierzchnię niektórych opraw zniszczyły owady, widoczne są też ślady zawilgocenia. Dużo zapięć, klamer i więzów jest niekompletnych. Po niektórych zostały tylko ślady.

Wśród opraw druków z XVI wieku 481 to oprawy oryginalne (z XVI wieku). 244 woluminy posiadają oprawy z XVII wieku, 118 - z XVIII wieku, 59 - z XIX$\mathrm{XX}$ wieku, a 42 są pozbawione opraw (uległy zniszczeniu).

Wiele opraw posiada ślepe wytłoki. Przedstawiają one przede wszystkim sceny biblijne ze Starego i Nowego Testamentu ${ }^{117}$. Są również ślepe wytłoki chrystologiczne ${ }^{118}$, hagiograficzne (święci) ${ }^{119}$, aretologiczne (cnoty) $)^{120}$, reformacyjne ${ }^{121}$, monarchiczne ${ }^{122}$, klasyczne ${ }^{123}$, heraldyczne ${ }^{124}$, mitologiczne i alegoryczne ${ }^{125}$.

${ }^{114}$ Sd 57, Sd 405, Sd 608, Sd 615.

${ }^{115}$ De 243, De 569a, De 691.

${ }^{116} \mathrm{Sd} 52$.

${ }^{117}$ Grzech pierworodny, Melchizedek, Abraham, Abraham i Izaak, Jakub, złoty cielec, Prawo, wąż miedziany, Zwiastowanie, Wcielenie, Boże Narodzenie, rzeź niewiniątek, chrzest w Jordanie, uzdrowienie Samarytanina, Przemienienie, droga krzyżowa, ukrzyżowanie, zdjęcie z krzyża, Zmartwychwstanie, Wniebowstąpienie, odkupienie, potępienie.

118 Jezus, Chrystus, Dobry Pasterz, Frasobliwy, Ukrzyżowany, oblicze Pańskie, naśladowanie, Zmartwychwstały, Baranek paschalny, Zbawiciel, Baranek Boży, Pantokrator, Tron Łaski, Trójca Święta.

${ }^{119}$ Adam i Ewa, Ewa, Mojżesz, Dawid, Salomon, Izajasz, Debora, Joel, Judyta, Anna (Matka Maryi), Maryja, Józef Oblubieniec, Jan Chrzciciel, Jan Ewangelista, Łukasz, Marek, Mateusz, Jakub, Paweł, Piotr, Jerzy, Krzysztof, Mikołaj.

${ }^{120}$ Cnota, wiara, nadzieja, miłość, roztropność, sprawiedliwość, umiarkowanie, męstwo, cierpliwość, jałmużna, mądrość.

${ }^{121}$ Jan Hus, Erazm z Rotterdamu, Marcin Luter, Filip Melanchton.

${ }^{122}$ Karol V, Paweł III Papież, Ferdynand, Fryderyk Saski, Joachim Fryderyk, Izabela, Ludwik, Zygmunt Stary, Bona Sforza, Zygmunt August, Katarzyna Szwedzka, Barbara Radziwiłłówna, Stefan Batory.

${ }^{123}$ Ajschylos, Cyceron, Juliusz Cezar, Owidiusz, Wergiliusz, Hektor, Helena, Eneasz, Penelopa.

${ }^{124}$ Cesarstwo, Gdańsk, Saksonia, Jan Dantyszek, Marcin Kromer, Juliusz Brunszwicki, Reinhold Heidenstein, gryfy, klucze Piotrowe, lilie andegaweńskie, orzeł, Pogoń, topór, trójząb, TB.

125 Apollo, Chloe, Lukrecja, Putta, Sybilla, Wenus, Maszkarony, muzy, mądrość, męstwo, miłość, nadzieja, sprawiedliwość, szczęście, wiara, niewiasta z lilią, okazja, polowanie z psami na jelenia, półpostać z mieczem, sowy. 


\section{Zdobienia}

Druki z XVI wieku zwykle nie są tak bogato zdobione jak inkunabuły. Wiele nie posiada żadnych zdobień. Niektóre mają barwione brzegi kart. Druk Sd 635 ma brzegi kart złocone i wzorkowane. W starszych drukach tekst - na wzór dawnych kodeksów rękopiśmiennych i inkunabułów - bywa rubrykowany, przeważnie kolorem czerwonym i niebieskim. Nie zawsze rubrykowanie obejmuje całą książkę, czasami tylko jej fragmenty bądź jedynie początek dzieła. Niektóre druki, szczególnie z 1. poł. XVI wieku, posiadają oprócz tradycyjnego czarnego dru$\mathrm{ku}$ - czerwony.

Wśród zdobień przeważają inicjały drzeworytowe, głównie czarne, rzadziej barwne. Niektóre posiadają bogatą floraturę, a nieliczne są barwione żółtą, zieloną, niebieską i czerwoną farbą.

W drukach odnaleźć można ilustracje drzeworytowe i miedziorytowe. Część z nich to zdobienia karty tytułowej, niektóre zaś znajdują się w środku bądź na końcu tekstu. Są to całostronicowe lub mniejsze kompozycje figuralne. Czasami przedstawiają autora, a czasami osobę, której dzieło jest dedykowane lub postacie ojców Kościoła, papieży, świętych, monarchów lub przywódców reformacji. Zdarzają się ilustracje maszyn, narzędzi wojennych, urządzeń astronomicznych, a w drukach medycznych - części ludzkiego ciała.

Efektownie pod względem bogactwa materiału ilustracyjnego wyglądają dwa wydania Biblii, gdzie szczególnie w Starym Testamencie i Apokalipsie znajdują się barwione sceny drzeworytowe.

Arcydziełem sztuki zdobniczej jest atlas Theatrum orbis terrarum Abrahama Orteliusa ${ }^{126}$. Jest to czwarte uzupełnione wydanie, opracowane i wydane w roku 1592. Zawiera 105 map z odwzorowaniem regionów świata oraz 26 map historycznych dołączonych w Perargonie. Atlas otwiera mapa świata, następnie są mapy ogólne kontynentów oraz mapy szczegółowe regionów. Większość map ujęta jest w ramkę ozdobną. Tytuły map umieszczone są w ozdobnych ornamentowych kartuszach. W przypadku niektórych map wymienione jest także nazwisko kartografa będącego jej autorem. W polu niektórych map umieszczono dodatkowo opi-

126 Abraham Ortelius (1527-1598) był przedstawicielem holenderskiej szkoły kartografii W dobie jej największego rozkwitu. W początkowym okresie zajmował się on handlem mapami i działalnością antykwaryczną. W 1560 roku zetknął się z Gerardem Kremerem i pod jego wpływem podjął pracę nad zorganizowaniem, a potem wydaniem pierwszego systematycznego zbioru map, czyli atlasu Theatrum orbis terrarum. Ortelius uznawany jest za twórcę pierwszej jednolitej koncepcji atlasu map. Swój zbiór opracował on bardzo starannie. Utrzymywał bardzo szerokie kontakty z wieloma kartografami, w czym niewątpliwie pomagała mu znajomość siedmiu języków (flamandzki, łaciński, grecki, włoski, francuski, niemiecki i angielski). Zwracał się do kartografów z prośbą o przesyłanie map wraz z jednoczesnym pozwoleniem na przedruk. Zebrane materiały w ujednoliconym formacie i dopracowanej przez wybitnego niemieckiego miedziorytnika Fransa Hogenberga formie, doczekały się pierwszej publikacji w 1570 roku. Pierwsze wydanie zawierało 70 map na 53 planszach. Wraz z upływem czasu Ortelius stale aktualizował i uzupełniał swoje mapy. Ostatnie, piąte wydanie za jego życia, zawierało już 108 map - zob. M. Sirko, Zarys historii kartografii, Lublin 1999, s. 122-125; L.A. Brown, The Story of Maps, Boston 1950, s. 160-161; Mappae Mundi, Berlin 1958, s. 286-289; L. Bagrow, R.A. Skelton, Meister der Kartographie, Berlin 1964, s. 259. 
sy lub na marginesach tzw. parerga zawierające widoki miast lub sceny rodzajowe. Na odwrocie map znajdują się opisy regionu otwierane ręcznie kolorowanym inicjałem.

Kolejną część atlasu stanowi zbiór 26 map historycznych, czyli Parergon. Otwiera go oddzielny miedziorytniczy frontispis. Na karcie tej przedstawiona jest architektoniczna trójkondygnacyjna rama, nawiązująca swą formą do portalu. W górnej części umieszczony został w ornamentalnym obramowaniu napis $\mathrm{Pa}$ rergon (w thumaczeniu polskim: dodatek, uzupełnienie). W środkowej części, pomiędzy dwiema kolumnami, znajduje się tekst, w którym Ortelius uzasadnia decyzję dołączenia map historycznych do zbioru map zawartych w atlasie i obrazujących ówczesną sytuację polityczną świata. Zaznacza, że zachęcało go do tego kroku wiele osób zainteresowanych historią geografii. Na następnych kartach umieszczony został poemat pochwalny na cześć Orteliusa, królewskiego kartografa, napisany przez Jakuba Coliusa Orteliusa, oraz spis map zawartych w Parergonie.

Wszystkie mapy wykonane zostały bardzo precyzyjnie w technice miedziorytu, a następnie ręcznie pokolorowane farbami akwarelowymi. Zgodnie z ustaleniami znanymi od końca XV wieku wody oznaczono kolorem niebieskim, lasy zielonym, osiedla - czerwonym, a góry - brązowym ${ }^{127}$. Generalnie w treści kartograficznej map zastosowano pięć kolorów: żółty, zielony, pomarańczowy, niebieski i różowy. Gama kolorów zastosowanych do podbarwienia kartuszy była znacznie bogatsza. Ortelius duże znaczenie przywiązywał do formy swoich wydawnictw: do precyzyjnego rysunku map, ich formy estetycznej i starannej kolorystyki.

Do zbioru map dołączony został także Nomenclator, czyli spis nazw wszystkich miast i miejscowości, które wystąpiły w dziele Ptolemeusza Cosmographia. Ta część atlasu datowana jest na rok 1591. Poszczególne części spisu oddzielono od siebie miedziorytniczymi winietkami pokolorowanymi na żółto.

Egzemplarz nie posiada żadnych adnotacji ani pieczątek proweniencyjnych. Oprawa nie zachowała się. Brak danych o poprzednim właścicielu atlasu, jak również o sposobie jego pozyskania do zbiorów Biblioteki „Hosianum”. Egzemplarz ten nie jest notowany w katalogach kartograficznych zabytków polskich. W centralnym katalogu zbiorów kartograficznych w Polsce wymieniane są dwa inne egzemplarze prezentowanego wydania - z Biblioteki Narodowej w Warszawie i z Biblioteki Uniwersyteckiej we Wrocławiu ${ }^{128}$.

\section{Zakończenie}

Analiza szesnastowiecznego zasobu Biblioteki Wyższego Seminarium Duchownego Metropolii Warmińskiej „Hosianum” w Olsztynie odzwierciedla wysoką kulturę umysłową historycznej Warmii. Chociaż stare druki pochodzą z różnych kolekcji, ogromna większość z nich od początku znajdowała się w obrębie

${ }^{127}$ Sirko, Zarys historii kartografii, s. 125.

${ }^{128}$ D. Jutrzenka-Supryn, Dokumentacja prac konserwatorskich i restauratorskich: Atlas kartograficzny ,"Theatrum orbis terrarum” Abrahama Orteliusa wydany w Antwerpii w 1592 r., Toruń 2003, s. 5-8, 13. 
diecezji warmińskiej. Wartość tego księgozbioru podnoszą druki należące do przedstawicieli życia społecznego i religijnego, m.in. biskupów warmińskich, którzy piastowali ważne funkcje publiczne w Polsce i poza jej granicami, a także kanoników warmińskich, którzy dzięki studiom i podróżom po Europie, stawali się posiadaczami ciekawych ksiąg.

W zabytkowym zbiorze z XVI wieku przeważają dzieła religijne, zwłaszcza z zakresu literatury polemicznej, biblistyki i kaznodziejstwa. Gromadzono też piśmiennictwo prawnicze, historyczne, filozoficzne, filologiczne, geograficzne, medyczne oraz literaturę piękną (szczególnie starożytną). Większość druków, przeważnie $w$ języku łacińskim, pochodziła $z$ oficyn zagranicznych. $Z$ polskich oficyn przeważają druki krakowskie, co potwierdza prymat tego miasta w szesnastowiecznym drukarstwie polskim.

słowa kluczowe: Biblioteka „Hosianum”, stare druki z XVI wieku, Braniewo, Dobre Miasto, Frombork, Barczewo, Abraham Ortelius

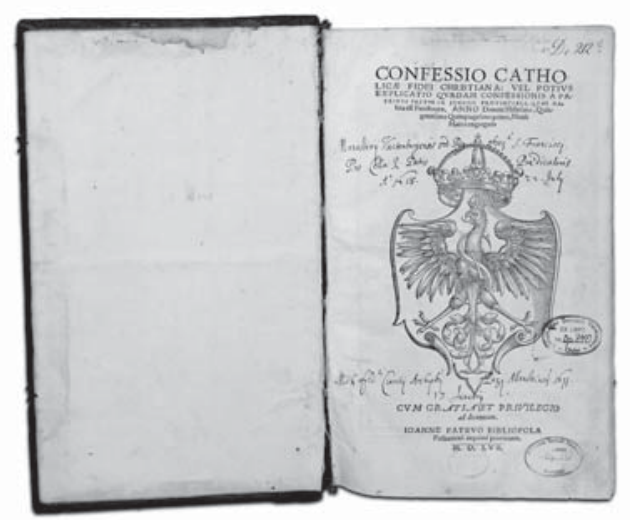

Fot. 1: Karta tytułowa dzieła: Stanisław Hozjusz, Confessio Catholicae Fidei Christiana, Mainz 1557, sygn. Dp 340/

Photo 1: The title card of the work: Stanisław Hozjusz, Confessio Catholicae Fidei Christiana, Mainz 1557, Ref. Dp 340 


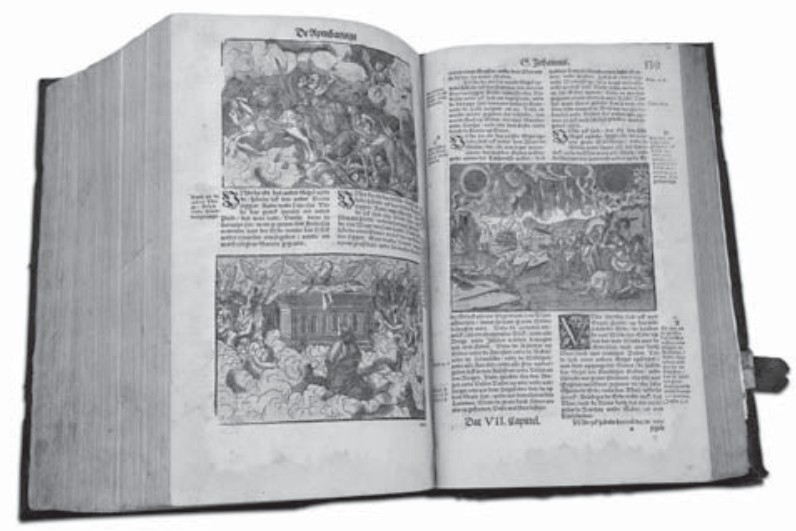

Fot. 2: Kolorowane ilustracje drzeworytnicze w dziele Biblia Germanica, Wittenberg 1569, sygn. Sd 123/

Photo 2: Colored woodcut illustrations in Bible Germanica, Wittenberg 1569, Ref. Sd 123

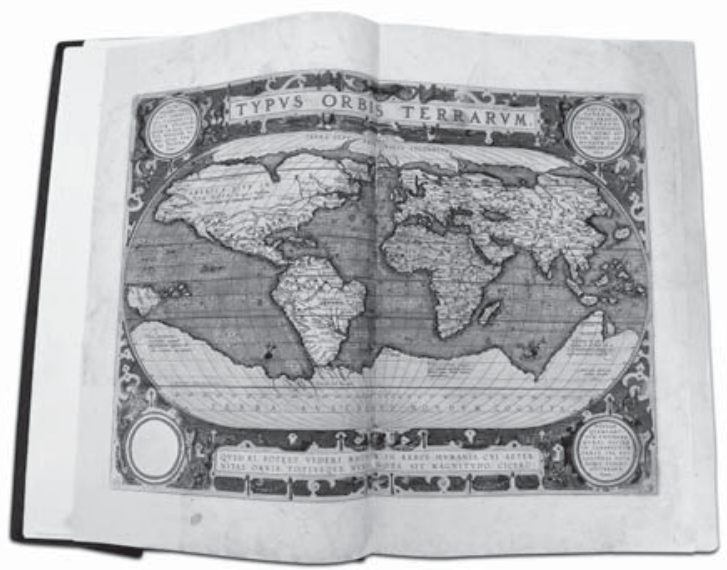

Fot 3: Mapa świata z dzieła: Abraham Ortelius, Theatrum orbis terrarum, Antwerpen 1592/ Photo 3: The map of the world from: Abraham Ortelius, Theatrum orbis terrarum, Antwerp 1592 


\title{
THE CHARACTERIZATION OF THE COLLECTION OF ANTIQUE BOOKS OF THE SIXTEENTH CENTURY OF THE LIBRARY OF HOSIANUM, THE SEMINARY OF THE ARCHDIOCESE OF WARMIA IN OLSZTYN
}

\begin{abstract}
Summary
The collection of antique books of the sixteenth century of the Library of Hosianum, the Seminary of the Archdiocese of Warmia in Olsztyn includes 1559 publications. This is not a homogeneous collection, as the library collected vintage books from all over the Diocese of Warmia after World War II. Most publications come from Braniewo, Dobre Miasto, Barczewo and Frombork. They were released in 89 print centers, by 497 publishers. Most were written in Latin. Among the works in the Polish language, there are two copies of the Leopolite Bible, postils, sermons, religious literature and state publications.

In the sixteenth-century book collection of the Library „Hosianum” 25 publications are works of ancient writers. An essential part of the literature of that period was represented by religious works.

A Patristic period is represented by works of: Tertullian, Origen, St. Cyprian, St. Athanasius, St. Gregory of Nazianzus, St. Gregory of Nyssa, St. Ambrose, St. Jerome, St. John Chrysostom, St. Augustine, St Cyril of Alexandria, Theodoret of Cyrus, Cassiodorus, St. Gregory the Great, St. Isidore of Seville, St. Leo I the Great. The theology of the Middle Ages is represented by works of: St. Anselm of Canterbury, St. Bernard of Clairvaux, Peter Lombard, St. Albert the Great, St. Bonaventure, St. Thomas Aquinas, Nicholas of Lyra, St. Antoninus of Florence. There are the work of reformers: Erasmus of Rotterdam, Martin Luther, Philipp Melanchthon, John Calvin, John Bugenhagen, and counter reformers: St. John Fisher, John Eck, Peter Soto, Melchior Cano, St. Robert Bellarmine and Johannes Cochlaeusa.

Martin Luther is the most often represented author in the sixteenth-century book collection in the Library „Hosianum”(41 works). There are also plenty of books by the authors from the Society of Jesus: St. Peter Canisius, St. Francis Suarez and many others more or less known. Sixteen works are written by Louis of Granada - a very popular Dominican mystic. In addition, there are works of eminent bishops of Warmia who held important church and state positions: John Dantiscus, Stanislaus Hosius, Marcin Kromer. The collection includes the works of native authors - priests of Warmia, canons and Jesuits working in Braniewo: John Benedict Solfa, Anthony Possevino, Thomas Treter, Fabian Kwadrantyn (Quadrantinus), Frederic Bartsch. There are also the poems of the first humanist poet, born in Warmia, Eustace Knobelsdorf.

In the collection we can also find the works of other famous Polish authors, such as: Andrzej Frycz Modrzewski, Mikołaj Rej, Jakub Górski, Rev. Piotr Skarga, Stanisław Reszka. The sixteenth-century book collection of the Library „Hosianum” contains many editions of the Bible (26), liturgical books (among them Missals and agendas of Warmia and the agenda of Cracow of 1517), martyrologies, sermons, codes of civil and canon law. There are the works of the poet Francis Petrarch, works on philosophy, rhetoric, history, literature, astronomy, biology, medicine, economics, geography, and among them the works of the eminent cartographer at a Spanish court - Abraham Ortelius.

Some volumes are bound in elaborate sixteenth-century bindings, others have a beautiful decoration in the form of woodcut and copperplate illustrations. The atlas Theatrum orbis terrarum by Abraham Ortelius of 1592 is a masterpiece of decorative art.

The analysis of the collection of the Library „Hosianum” in Olsztyn reflects the high
\end{abstract}


intellectual culture of historical Warmia. The value of this library is increased thanks to publications belonging to the representatives of the social and religious life, including bishops of Warmia, who held important public positions in Poland and abroad, as well as the Canons of Warmia, who through studies and travels in Europe, became the owners of valuable and interesting books.

Keywords: Library „Hosianum”, antique books of the sixteenth century, Braniewo, Dobre Miasto, Frombork, Barczewo, Abraham Ortelius 